\title{
Temperature and Air Velocity Simulation on Sago Starch Pneumatic Conveying Recirculated Dryer Using Ansys Fluent
}

\author{
Abadi Jading1*, Nursigit Bintoro², Lilik Sutiarso², Joko Nugroho Wahyu Karyadi² \\ ${ }^{1}$ Jurusan Teknologi Pertanian, Fakultas Teknologi Pertanian, Universitas Papua, \\ Jl. Gunung Salju, Amban, Manokwari, Papua Barat 98314, Indonesia \\ 2Departemen Teknik Pertanian dan Biosistem, Fakultas Teknologi Pertanian, Universitas Gadjah Mada, \\ Jl. Flora No. 1, Bulaksumur, Yogyakarta 55281, Indonesia \\ *Email: a.jading@unipa.ac.id
}

Submisi: 23 Januari 2017; Penerimaan: 30 November 2017

\begin{abstract}
Pneumatic Conveying Recirculated Dryer (PCRD) is one of many driers used for drying wet sago starch. The most important components of this PCRD machine are the vertical pipe and the u-bend. The vertical pipe and the u-bend are the primary drying spaces. They must have a good temperature distribution and air velocity dryer. To observe the process of temperature distribution and the air velocity dryer in the vertical pipe and u-bend, Computational Fluid Dynamics (CFD) analysis is required. The research was aimed to analyze the temperature distribution and the air velocity dryer flow in the recirculated pipe of PCRD machine by using CFD analysis. The analysis was based on the variance of the temperature, the air velocity, and the height of the vertical pipe in PCRD machine. The analysis was conducted using Ansys Workbench Fluid Flow ver. 15. This software was used to simulate the temperature and the air flow velocity in the vertical pipe and the u-bend. However, the flow characteristics and patterns of the wet sago starch were not included in the discussion. The turbulence model used in the simulation was the Reynold Stress Models (RSM). The result of the simulation showed that the temperature along the vertical pipe and the u-bend was distributed evenly. The error value between the result of the simulation and the observation was low $(0.10-2.04 \%)$. The average test value with paired $\mathrm{t}$-test showed that the simulation and observation result was not significantly different. This results indicated that the simulation fit well with the observation value or the real condition in the PCRD machine. The distribution of the temperature and the air velocity dryer in the vertical pipe and the u-bend were able to reduce the moisture content on sago starch from $31 \%(w b)$ to $9 \%(w b)$. Therefore, the vertical pipe and the u-bend design was appropriate to use in PCRD machine for drying wet sago starch.
\end{abstract}

Keywords: Ansys fluent; computational fluid dynamics; pneumatic conveying recirculated dryer; sago starch; temperature

\section{INTRODUCTION}

Pneumatic conveying dryer (PCD) is one of the drying machines widely used in food processing industry, specifically flour-based products. One of the developments on PCD machines is the addition of material recirculation process to reduce the length of the vertical pipe used. Therefore, in this research a pneumatic conveying recirculated dryer (PCRD) has been designed to dry wet sago starch or generally referred to as wet sago flour. The PCRD machine consists of seven main components, namely heating furnace, with $12 \mathrm{~kg}$ LPG fuel; blower and disintegrator; feeder; recirculation pipe; recirculation cyclone; output cyclone; and controller (Jading et al., 2016). However, the most essential component in determining the material recirculation process is the length of vertical pipe and the u-bend, therefore, the focus of this research is on the vertical pipe (upriser and downcomer) and the u-bend. According to (Bhattarai, et al., 2014), on a pneumatic system dryer, the vertical pipe also functions as the main drying chamber, therefore, the temperature distribution and drying air speed in the vertical pipe is determinant for the quality and quantity of drying results. To analyze the temperature distribution and the speed of drying air in the vertical pipe and u-bend of the PCRD machine for drying wet sago starch, a simulation is performed using a computational fluid dynamics (CFD). Dyah et al. (2003) argued that the CFD method is widely used to analyze temperature distribution because it has advantages such as the ability to solve 2 dimensional or 3 dimensional equations faster and can be performed simultaneously. Furthermore, the development of computation technology has made the CFD method as one of the main powers and devices to design and optimize pneumatic dryers (El-Behery et. al., 2013; Norton and Sun, 2006). One of the software that supports CFD is 
ansys fluent, which has capability to analyze fluids flow system; heat transfer; and combustion, with computer simulation based on volume method up to finite volume method (El-Behery et al., 2013). Ansys fluent has been developed into a software package, namely ansys design modeler; ICEM; and fluent (Ansys Fluent, 2013).

There are several assumptions used to simulate temperature distribution and drying air speed using CFD with ansys fluent software. First, in the recirculation pipe of PCRD machine, which is the model, the air flow in the vertical recirculation pipe and the $u$-bend is turbulent. Second, the air flows in steady; adiabatic condition; the physical characteristics of drying air (density, heat type, conductivity, and viscosity) is constant. Third, the environmental temperature is constant; the air flow speed is uniform; there is no mix between environmental air and the hot air which enters into the vertical pipe and the ubend. Fourth, the characteristics and pattern of wet sago starch flow in the pipe is neglected. Based on the above assumptions, then the model used to analyze temperature distribution and drying air speed is the Reynold Stress Model (RSM).

The RSM model is a turbulence model which is most precise on fluent and is close with Navier-Stokes' equation by solving transport equation for Reynold's tension together with dissipation rate. The RSM model is suitable for in-pipe flow and cyclone which pass a revolving track or recirculation. RSM model can accommodate anisotropy of turbulence that has an important influence on the main flow (Caroko and Suyitno, 2008; Tuakia, 2008). RSM model is derived from Navier Stokes' equation (Kornev, 2013).

This research aimed to analyze the distribution of temperature and speed of dryer air flow inside the vertical recirculation pipe (upriser, u-bend, and downcomer) and u-bend based on the variation of dryer air temperature, dryer air speed, and the height of vertical pipe in the PCRD machine to dry wet sago starch using ansys fluent software.

\section{RESEARCH METHOD}

\section{Materials and Tools}

The materials used in this research were wet sago starch or commonly referred to as wet sago flour with $31 \%$ (wb) initial water content, particle diameter 2.36 $\mathrm{mm}, 550 \mathrm{~kg} / \mathrm{m}^{3}$ density, and $2.1 \mathrm{~kJ} / \mathrm{kg}{ }^{\circ} \mathrm{C}$ specific heat. The vertical and u-bend pipes used on PCRD machine were constructed from stainless steel with a $0.1016 \mathrm{~m}$ (4 inches) diameter. The vertical pipe (upriser) was connected to the u-bend and vertical pipe (downcomer)

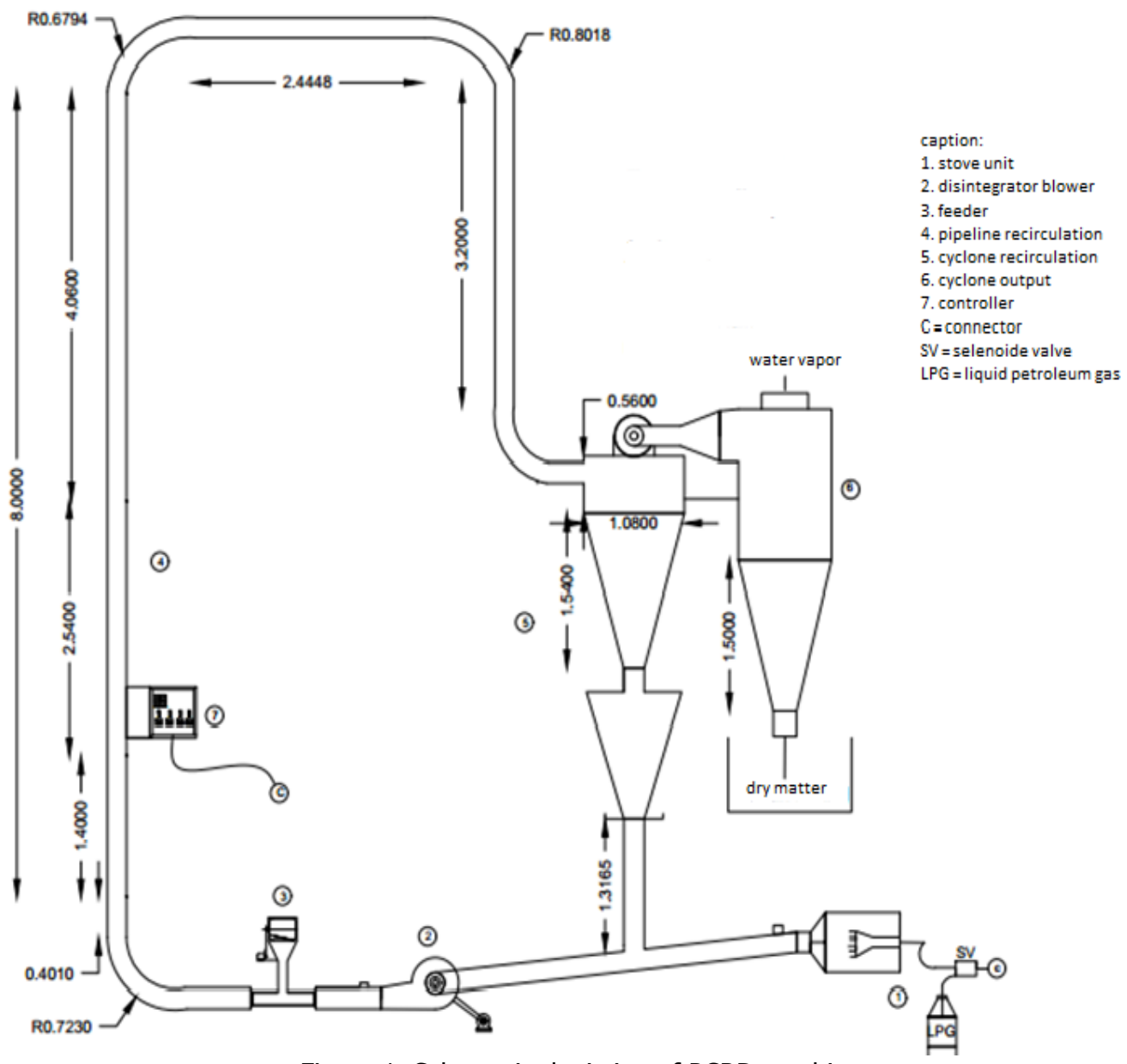

Figure 1. Schematic depiction of PCRD machine 
continuously through two curvatures with $0.30 \mathrm{~m}(r=15$ $\mathrm{cm}$ ) diameter, with u-bend pipe angle of $15^{\circ}$. The schematic picture of PCRD machine is described in Figure 1 (Jading et al., 2016; Jading et al., 2018). In this research, three variations of vertical pipe length were used, namely $5.8 \mathrm{~m} ; 6.8 \mathrm{~m}$; and $7.8 \mathrm{~m}$ (upriser, u-bend, and downcomer). To measure the temperature and speed of the drying air in the vertical and u-bend pipes, a digital thermometer with type- $K$ thermocouple (4 channel TM 946 LUTRON-Taiwan) and an air flow meter (flexible thermo-anemometer KW06-562 KRISBOW-Indonesia) were used. Meanwhile, the software used for simulation was ansys fluent (Ansys, Inc. 2014-USA) free software for student which consists of ansys design modeler, ICEM, and fluent. To perform the vertical and u-bend pipe's geometry, an Autodesk AUTOCAD version 2016 (Autodesk, Inc. 2015-USA) free software for student installed in a laptop with Core i3-4030u, $1.9 \mathrm{GHz}$ Intel CPU, 4GB memory, and 500GB hard disk.

\section{Research Procedures}

This research was conducted in two stages. First, the measuring and observation of temperature and speed of drying air in the vertical and u-bend pipes of the PCRD machine. The next stage was simulation the temperature and speed of drying air in the vertical and u-bend pipes of the PCRD machine using ansys fluent. The drying air temperature and speed measurement was performed on 6 point $\left(T_{1}-T_{6}\right)$ inside the vertical and $u$-bend pipes of the PCRD machine. The temperature measurement was conducted using a digital thermometer with a type-K thermocouple. The air speed was measured using an air flow meter. The points for measurement of temperature, drying air speed, geometric shape, and vertical and ubend pipes mesh of the PCRD machine can be seen in Figure 2.

The variable value of drying air temperature $\left(T_{\mathrm{u} 1}\right)$, drying air speed $\left(\mathrm{V}_{\mathrm{u}}\right)$, and vertical pipes's length (upriser and downcomer) of the recirculation pipe $\left(L_{p v}\right)$, are as presented in Table 1 . The simulation of drying air temperature distribution and speed inside the vertical and $u$-bend pipes of the PCRD was performed using ansys fluent software version 15 . Whereas the formation of vertical and u-bend pipes' geometry uses AUTOCAD Version 2016 software. The procedure of simulation process applied in this research can be seen in Figure 3.

One of the most important stages in the simulation using ansys fluent is determining the boundary conditions. The boundary conditions include inlet, outlet, wall, and other variables, and inputting information or data into the determined boundaries (Fluent, 2013b; Tuakia, 2008). In this research, boundary conditions have been determined based on the characteristics of drying air flow inside the pipe. So, the inlet velocity was chosen as inlet, pressure outlet as outlet, and the stainless steel vertical and u-bend pipes as wall. The inlet value used is temperature, drying air speed, and the vertical pipe length of the PCRD machine. The inlet value used can be seen in Table 1.

Fluids physical characteristics value (drying air) and materials used in this research are secondary data obtained from Singh and Heldman, (2009). The values can be seen in Table 2 .

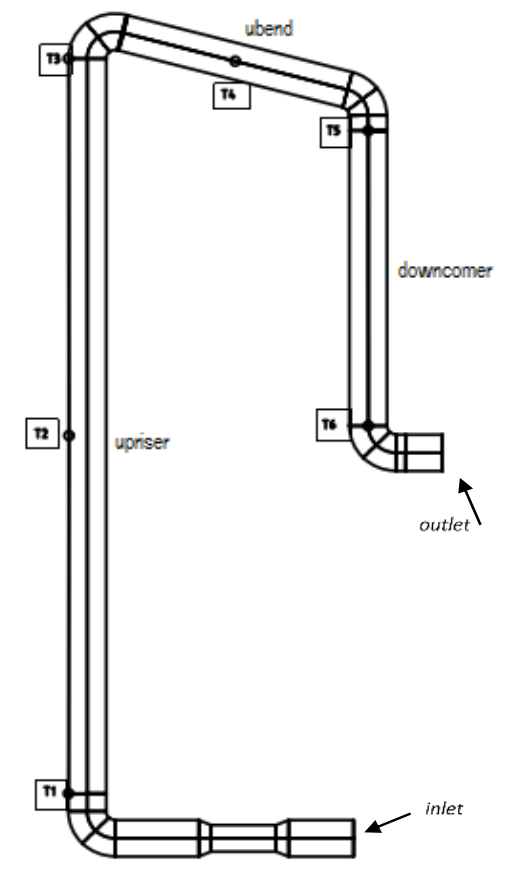

a)

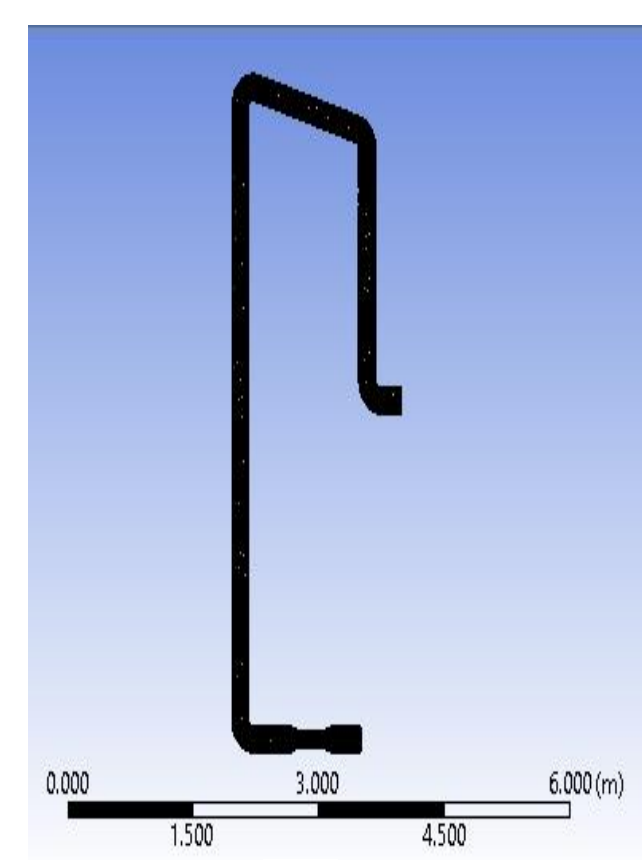

b)

Figure 2. Vertical and u-bend pipes: a) geometric form and temperature observation points $\left(\mathrm{T}_{1}-\mathrm{T}_{6}\right)$, and b) mesh form and ansys fluent results 


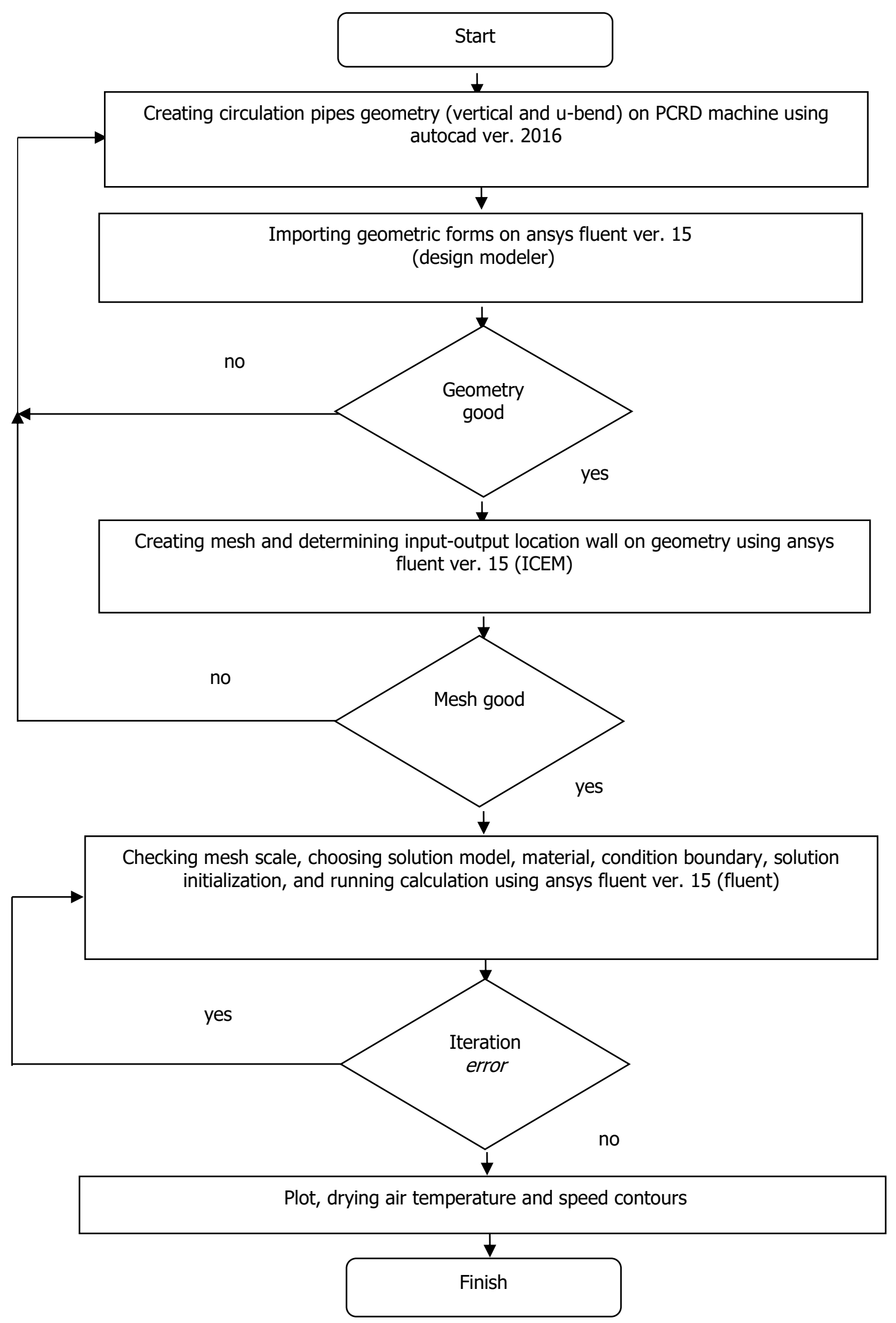

Figure 3. Procedure of drying air temperature and speed using Autocad version 2016 and ansys fluent version 15 
Table 1. Inlet variables for ansys fluent simulation

\begin{tabular}{lcc}
\hline Inlet variables & Variation value & Constant variable value \\
\hline Drying air temperature, $\mathrm{T}_{\mathrm{u} 1}\left({ }^{\circ} \mathrm{C}\right)$ & $75,100,125$ & $\mathrm{v}_{\mathrm{u}} 28 \mathrm{~m} / \mathrm{s}$, and $\mathrm{L}_{\mathrm{pv}} 7.8 \mathrm{~m}$ \\
Drying air speed, $\mathrm{v}_{\mathrm{u}}(\mathrm{m} / \mathrm{s})$ & $15,28,31$ & $\mathrm{~T}_{\mathrm{u} 1} 100{ }^{\circ} \mathrm{C}$ and $\mathrm{L}_{\mathrm{pv}} 7.8 \mathrm{~m}$ \\
Vertical pipe height, $\mathrm{L}_{\mathrm{pv}}(\mathrm{m})$ & $5.8,6.8,7.8$ & $\mathrm{~T}_{\mathrm{u} 1} 100^{\circ} \mathrm{C}$ and $\mathrm{v}_{\mathrm{u}} 28 \mathrm{~m} / \mathrm{s}$ \\
\hline
\end{tabular}

Table 2. Fluids physical characteristics value (air) and materials used in ansys fluent simulation

\begin{tabular}{|c|c|c|c|c|c|c|}
\hline Fluids & $\begin{array}{c}\text { Density, } \rho \\
\left(\mathrm{kg} / \mathrm{m}^{3}\right)\end{array}$ & $\begin{array}{l}\text { Heat type, } \\
\mathrm{cp}(\mathrm{j} / \mathrm{kgK})\end{array}$ & $\begin{array}{c}\text { Viscosity, } \mu \\
(\mathrm{kg} / \mathrm{m} . \mathrm{s})\end{array}$ & $\begin{array}{l}\text { Heat Conductivity, } \mathrm{K} \\
(\mathrm{W} / \mathrm{mK})\end{array}$ & $\begin{array}{c}\text { Sound speed, } \\
M(\mathrm{~m} / \mathrm{s})\end{array}$ & Mach Count \\
\hline $\begin{array}{l}\text { Temperature } 75 \\
{ }^{\circ} \mathrm{C}\end{array}$ & 0.982 & 1048.5 & $2.0594 \times 10^{-5}$ & 0.0289 & 374 & 1.1 \\
\hline $\begin{array}{l}\text { Temperature } \\
100^{\circ} \mathrm{C}\end{array}$ & 0.916 & 1022.0 & $2.1673 \times 10^{-5}$ & 0.0307 & 387 & 1.1 \\
\hline $\begin{array}{l}\text { Temperature } \\
125^{\circ} \mathrm{C}\end{array}$ & 0.848 & 1026.0 & $2.2948 \times 10^{-5}$ & 0.0325 & 400 & 1.2 \\
\hline Material & $\begin{array}{l}\text { Density, } \rho \\
\left(\mathrm{kg} / \mathrm{m}^{3}\right)\end{array}$ & $\begin{array}{l}\text { Heat type, } \\
\mathrm{cp}(\mathrm{j} / \mathrm{kgK})\end{array}$ & $\begin{array}{c}\text { Electric } \\
\text { Conductivity } \\
(1 / \text { ohm })\end{array}$ & $\begin{array}{l}\text { Heat Conductivity, } \mathrm{K} \\
(\mathrm{W} / \mathrm{mK})\end{array}$ & - & - \\
\hline Stainless steel & 8030 & 50.48 & $8,330,000$ & 16.27 & - & - \\
\hline
\end{tabular}

\section{Validation between Simulation and Observation Temperature}

To determine the accuracy level of simulation results, validation is performed based on the methods used by Yani et al. (2007) and Anisum et al. (2016). The validation is performed by comparing between simulation output (predicted value) with observation by calculating the error value. In this research, the error value between simulation result and observation is calculated using Equation 1.

$$
e=\frac{T_{u-s i m}-T_{u-o b s v}}{T_{u-s i m}} \times 100
$$

in which e is the discrepancy (error) between simulation result and observation or measurement (\%), $\mathrm{T}_{\mathrm{u}^{-}}$sim is the drying air temperature in simulation $\left({ }^{\circ} \mathrm{C}\right)$, and $\mathrm{T}_{\mathrm{u} \text {-obsv }}$ is the temperature of drying air as the result of PCRD machine measurement $\left({ }^{\circ} \mathrm{C}\right)$. Then, a statistics analysis is performed using a paired samples t-test with SPSS 23 (IBM Corporation 2015-USA) free software for student, to determine the comparison between the average output values of simulation and observation, with an assumption that the variance of both samples are similar.

\section{RESULTS AND DISCUSSION}

\section{Distribution of Drying Air Temperature and Speed Based on $T_{u 1}$ Variation}

The simulation results of drying air temperature distribution and speed based on drying air temperature variation ( $T_{u 1}$ ) inside the vertical and u-bend pipes of the PCRD machine can be seen in Figure 6. The Tu1 variations are $75^{\circ} \mathrm{C}, 100{ }^{\circ} \mathrm{C}$, and $125^{\circ} \mathrm{C}$, with drying air speed $(\mathrm{Vu})$ and vertical pipe length (upriser-u-bend-downcomer) and u-bend or ( $L_{p v}$ ) as constant, that was, $28 \mathrm{~m} / \mathrm{s}$ and $7.8 \mathrm{~m}$. Figure 4 shows the contour and the graphic of output drying air temperature and speed based on Tu1 $75^{\circ} \mathrm{C}$ variation. The simulation result showed that the temperature was evenly distributed in the vertical and u-bend pipes, but experiences a reduction from $75^{\circ} \mathrm{C}$ to $73{ }^{\circ} \mathrm{C}$ (inlet to outlet). The drying air speed inside the vertical and $u$-bend pipes at the inlet to outlet is around $0-8.383 \mathrm{~m} / \mathrm{s}$. Results of CFD simulation using ansys fluent software version 13 performed by (Bhattarai et al., 2014) based on drying air variation show that the drying air temperature along the vertical pipe of the PCD machine experiences a reduction. In this study, the temperature value along the vertical and $u$-bend pipes of PCRD machine were: $\mathrm{T}_{1}(0 \mathrm{~m}) 75^{\circ} \mathrm{C} ; \mathrm{T}_{2}(2.25 \mathrm{~m}) 74,1$ ${ }^{\circ} \mathrm{C} ; \mathrm{T}_{3}(4,5 \mathrm{~m}) 73,8{ }^{\circ} \mathrm{C} ; \mathrm{T}_{4}(5,1 \mathrm{~m}) 73,5{ }^{\circ} \mathrm{C} ; \mathrm{T}_{5}(5,7 \mathrm{~m})$ $73,2^{\circ} \mathrm{C}$; and $\mathrm{T}_{6}(7,8 \mathrm{~m}) 72,9^{\circ} \mathrm{C}$. It indicated that there was reduction along the vertical and u-bend pipes just like the one researched by Bhattarai et al. (2014).

Figure 5 and Figure 6 showed the output contour and graphic of drying air temperature and speed based on $\mathrm{T}_{u 1}$ variation of $100^{\circ} \mathrm{C}$ and $125^{\circ} \mathrm{C}$. The simulation results showed a similar distribution pattern $\mathrm{T}_{\mathrm{u} 1}$ variation of 75 ${ }^{\circ} \mathrm{C}$, in which the temperature was evenly distributed along the vertical and u-bend pipes with temperature reduction values between $100-93{ }^{\circ} \mathrm{C}$, and $125-122{ }^{\circ} \mathrm{C}$. The drying air speed value based on Tu1 variation of 100 ${ }^{\circ} \mathrm{C}$ and $125{ }^{\circ} \mathrm{C}$ was similar with the $\mathrm{T}_{\mathrm{u} 1}$ variation value of $75{ }^{\circ} \mathrm{C}$, that was, $0-8.383 \mathrm{~m} / \mathrm{s}$ (from inlet to outlet). The temperature value along the vertical and u-bend pipes based on $\mathrm{T}_{\mathrm{u} 1}$ variation of $100{ }^{\circ} \mathrm{C}$ and $125{ }^{\circ} \mathrm{C}$ also experience a reduction, namely $\mathrm{T}_{1}(0 \mathrm{~m}) 100{ }^{\circ} \mathrm{C}$ and 125 ${ }^{\circ} \mathrm{C} ; \mathrm{T}_{2}(2.25 \mathrm{~m}) 99.8{ }^{\circ} \mathrm{C}$ and $124{ }^{\circ} \mathrm{C} ; \mathrm{T}_{3}(4.5 \mathrm{~m}) 99.7^{\circ} \mathrm{C}$ and $123.4{ }^{\circ} \mathrm{C} ; \mathrm{T}_{4}(5.1 \mathrm{~m}) 99.3{ }^{\circ} \mathrm{C}$ and $123{ }^{\circ} \mathrm{C} ; \mathrm{T}_{5}(5.7$ m) $98.9^{\circ} \mathrm{C}$ and $122.9^{\circ} \mathrm{C}$; and $\mathrm{T}_{6}(7.8 \mathrm{~m}) 98^{\circ} \mathrm{C}$ and 122.5 ${ }^{\circ} \mathrm{C}$. It showed that drying air temperature variation ( $\left.\mathrm{T}_{\mathrm{u} 1}\right)$ 


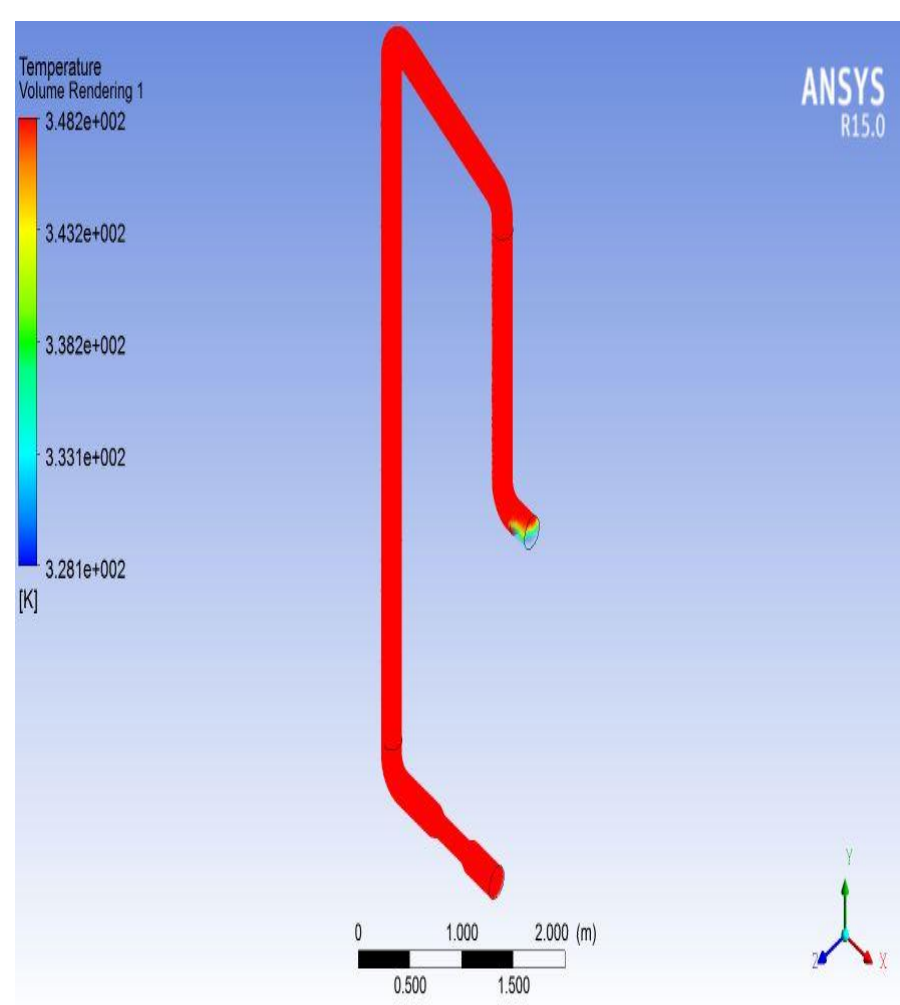

a)
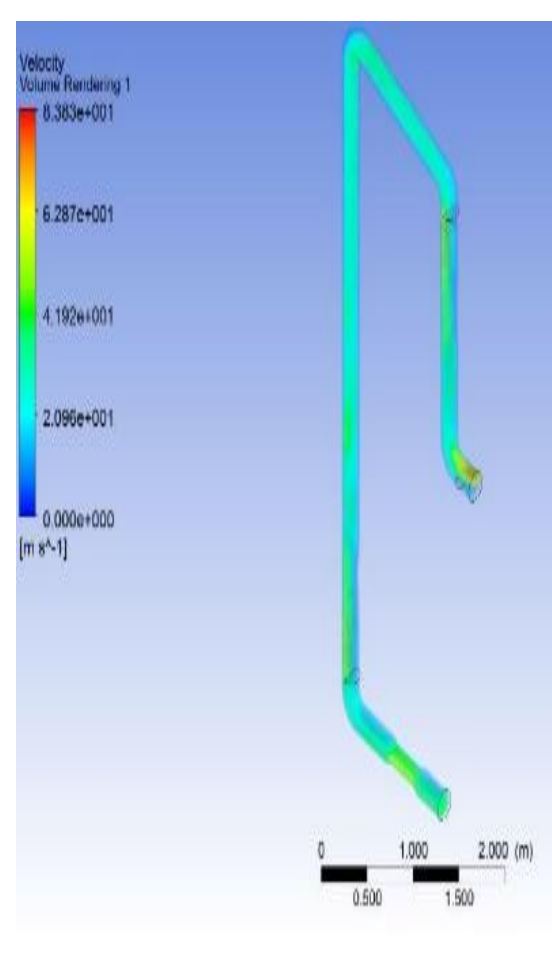

b)

Figure 4. Drying air temperature and speed distribution with $\mathrm{T}_{\mathrm{u} 1}$ variation of $75^{\circ} \mathrm{C}: \mathrm{a}$ ) temperature contour, and b) speed contour

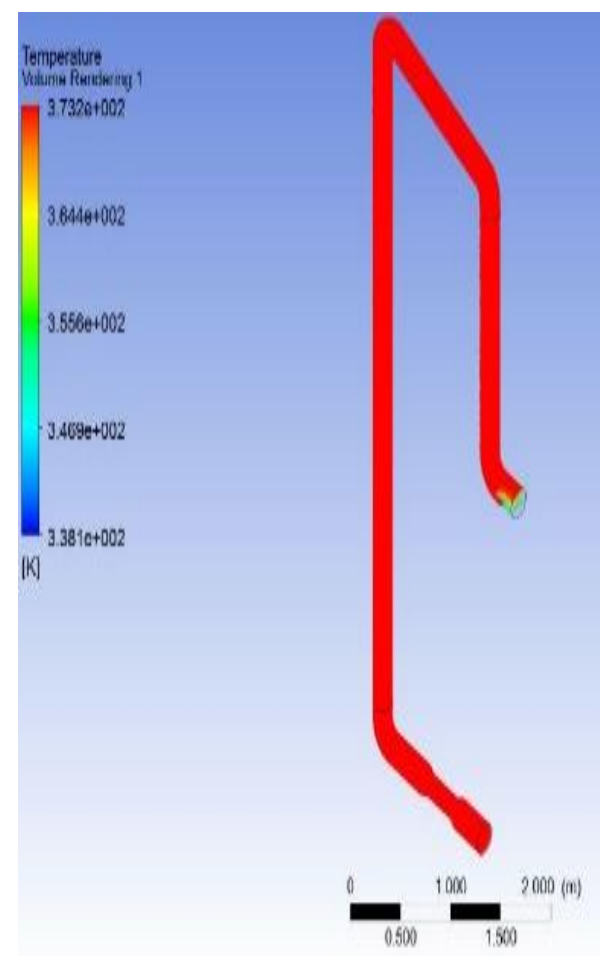

a)

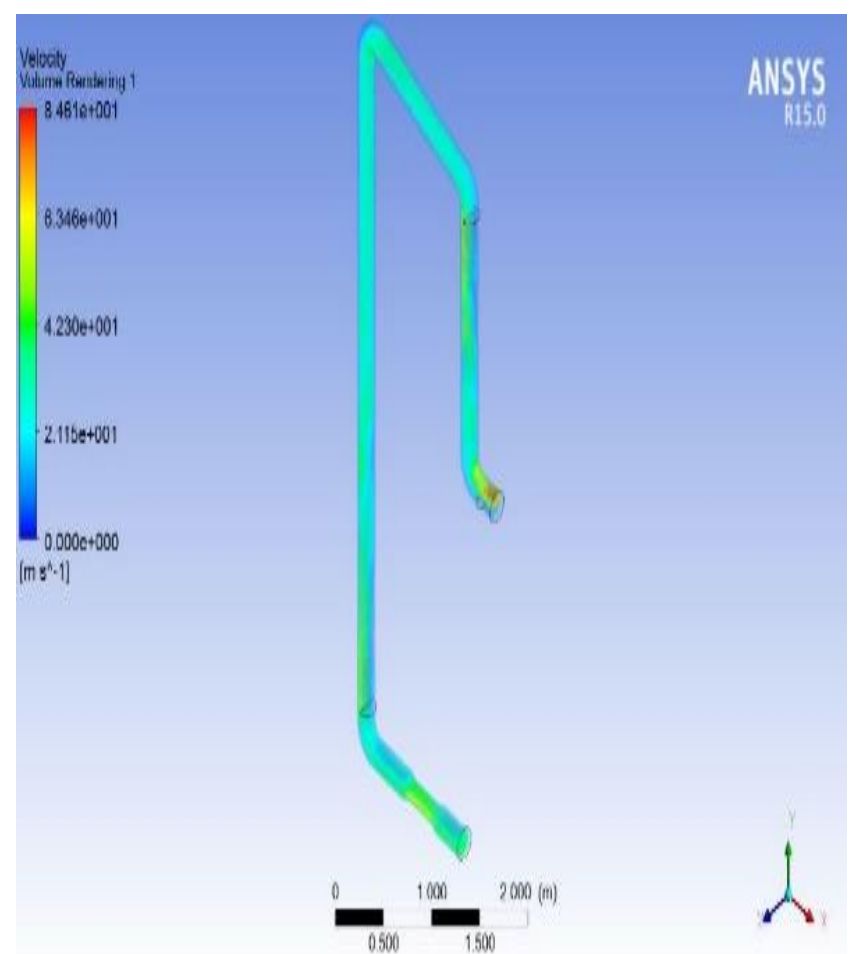

b)

Figure 5. Drying air temperature and speed distribution with $\mathrm{T}_{\mathrm{u} 1}$ variation of $100^{\circ} \mathrm{C}: \mathrm{a}$ ) temperature contour, and $\mathrm{b}$ ) speed contour 


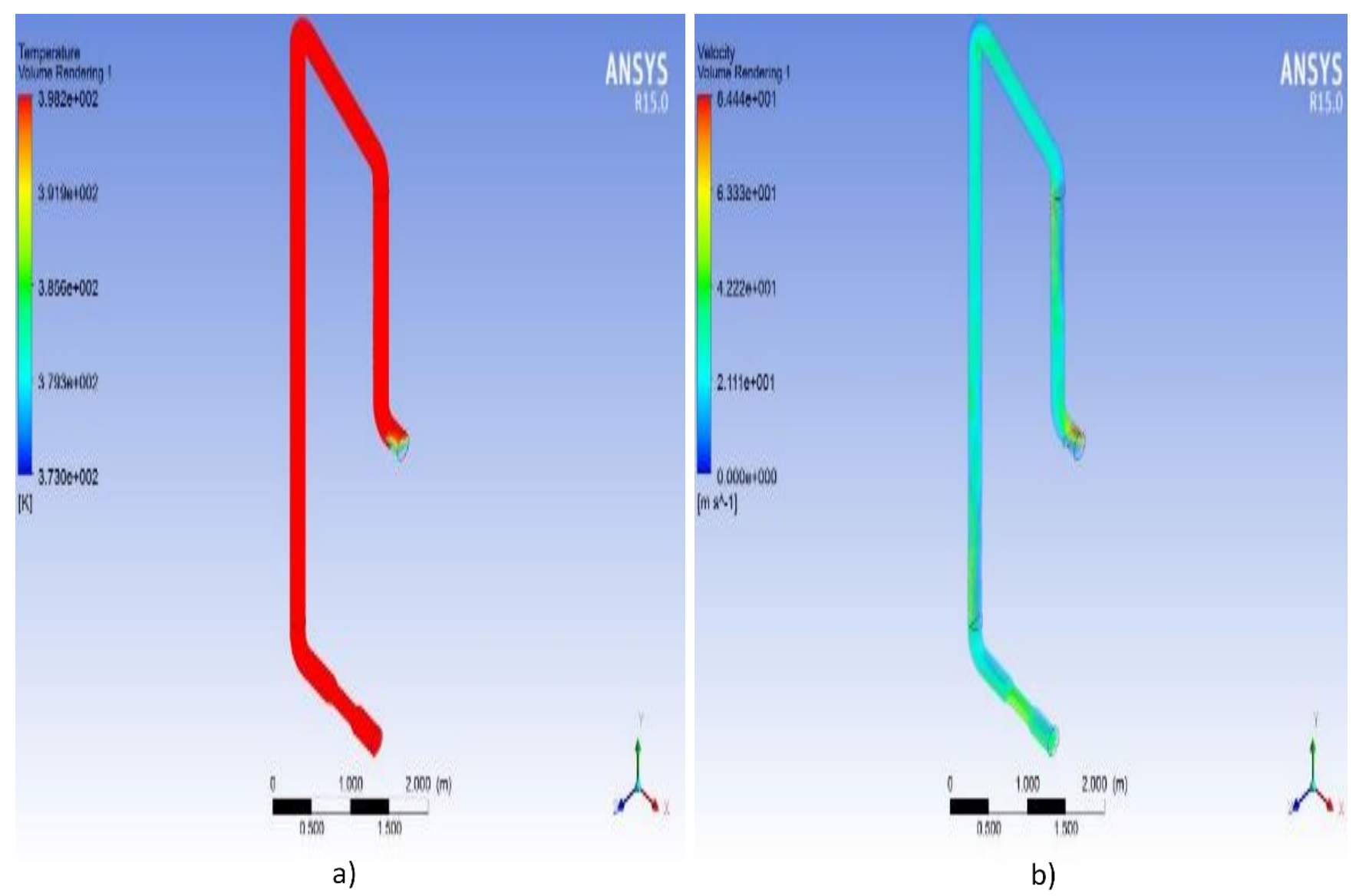

Figure 6. Drying air temperature and speed distribution with $\mathrm{T}_{\mathrm{u} 1}$ variation of $125^{\circ} \mathrm{C}$ : a) temperature contour, b) speed contour

was evenly distributed along the vertical and u-bend pipes $(7.8 \mathrm{~m})$, but experience a reduction at the end or outlet of pipe (Bhattarai et al., 2014).

\section{Drying Air Temperature and Speed Distribution Based on $v_{u}$ Variation}

Figure 7 and Figure 8 described drying air temperature and speed distribution inside the vertical and $u$-bend pipes as long as $7.8 \mathrm{~m}$ in the PCRD machine. The varied input variable is the drying air speed $\left(\mathrm{v}_{\mathrm{u}}\right) 15 \mathrm{~m} / \mathrm{s}$ and $31 \mathrm{~m} / \mathrm{s}$ with Tu1 constant, at $100{ }^{\circ} \mathrm{C}$. Figure 8 and Figure 9 indicated that drying air temperature and speed was evenly distributed along the vertical and u-bend pipes. However, the temperature value between inlet and outlet was decreasing from $100{ }^{\circ} \mathrm{C}$ to $96^{\circ} \mathrm{C}$ and from $100{ }^{\circ} \mathrm{C}$ to $98{ }^{\circ} \mathrm{C}$. Drying air speed between inlet and outlet was around $0-4.668 \mathrm{~m} / \mathrm{s}$ and $0-9.381 \mathrm{~m} / \mathrm{s}$. It showed that drying air speed influences the temperature value at the end (outlet) of the vertical and u-bend pipes, but the distribution was still even. The bigger the value of air speed, the bigger the value of temperature at the end of the pipe or outlet (Bhattarai et al., 2014). The temperature measurement on the vertical and u-bend pipes based on $v_{u}$ variation of $15 \mathrm{~m} / \mathrm{s}$ and $31 \mathrm{~m} / \mathrm{s}$ also experience a reduction from inlet to outlet, namely $\mathrm{T}_{1}(0$ m) $100{ }^{\circ} \mathrm{C} ; \mathrm{T}_{2}(2.25 \mathrm{~m}) 99{ }^{\circ} \mathrm{C} ; \mathrm{T}_{3}(4.5 \mathrm{~m}) 98.7{ }^{\circ} \mathrm{C} ; \mathrm{T}_{4}(5.1$ m) $98.4{ }^{\circ} \mathrm{C} ; \mathrm{T}_{5}(5.7 \mathrm{~m}) 98.1{ }^{\circ} \mathrm{C}$; and $\mathrm{T}_{6}(7.8 \mathrm{~m}) 98^{\circ} \mathrm{C}$.

\section{Drying Air Temperature and Speed Based on $L_{p v}$ Variation}

Figure 9 and Figure 10 described the drying air temperature and speed distribution inside the vertical and u-bend pipes of the PCRD machine based on the vertical pipe (upriser-ubend-downcomer) lengths ( $\left.L_{p v}\right)$ $5.8 \mathrm{~m}$ and $6.8 \mathrm{~m}$. Drying air temperature and speed was constant, that is, $\mathrm{T}_{\mathrm{u} 1} 100{ }^{\circ} \mathrm{C}$ and $\mathrm{v}_{\mathrm{u}} 28 \mathrm{~m} / \mathrm{s}$. Simulation results showed that the temperature in the pipe was evenly distributed with a reduction in temperature value from inlet to outlet from $100{ }^{\circ} \mathrm{C}$ to $99^{\circ} \mathrm{C}$ and from 100 ${ }^{\circ} \mathrm{C}$ to $98{ }^{\circ} \mathrm{C}$. The speed of drying air was between 0 $8.505 \mathrm{~m} / \mathrm{s}$ and $0-8.321 \mathrm{~m} / \mathrm{s}$. This shows that vertical and u-bend pipes' length variation does not influence temperature distribution along the pipes, except at the end of pipe (outlet), in which the temperature decreases. The observation result temperature values along the $5.8 \mathrm{~m}$ and $6.8 \mathrm{~m}$ vertical and u-bend pipes at the PCRD were similar. The values were: $\mathrm{T}_{1}(0 \mathrm{~m}) 100$ ${ }^{\circ} \mathrm{C}, \mathrm{T}_{2}(1.75 \mathrm{~m}) 99.9{ }^{\circ} \mathrm{C}, \mathrm{T}_{3}(3.5 \mathrm{~m}) 99.7{ }^{\circ} \mathrm{C}, \mathrm{T}_{4}(4.1 \mathrm{~m})$ 99.4 ${ }^{\circ} \mathrm{C}, \mathrm{T}_{5}(4.7 \mathrm{~m}) 98.9{ }^{\circ} \mathrm{C}$, and $\mathrm{T}_{6}(5.8 \mathrm{~m}) 98.3^{\circ} \mathrm{C}$.

$\mathrm{T}_{\mathrm{u} 1}, \mathrm{Vu}$, and Lpv showed that drying air temperature inside the pipes from the beginning (inlet) end to finishing (outlet) end was evenly distributed. However, the drying air temperature value experiences reduction. 


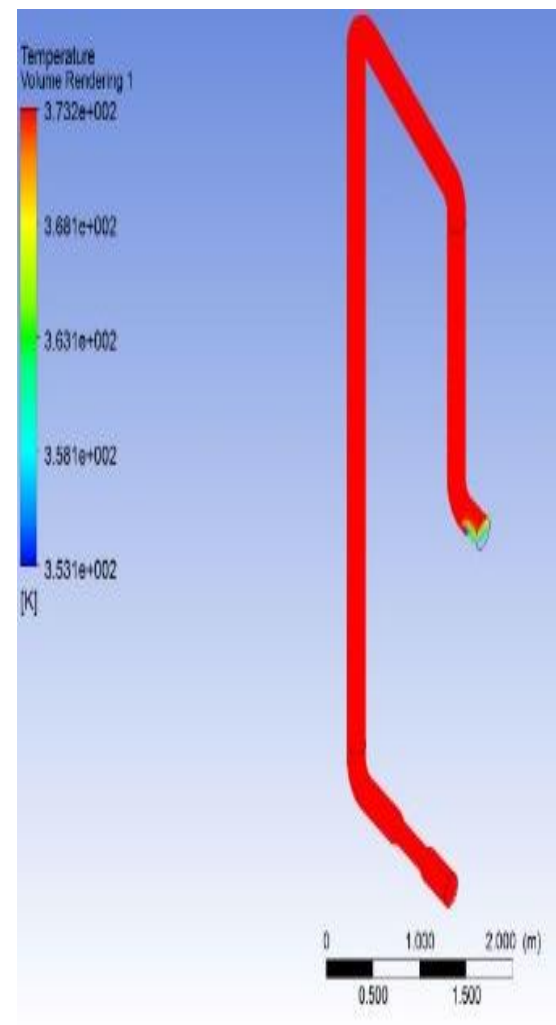

a)
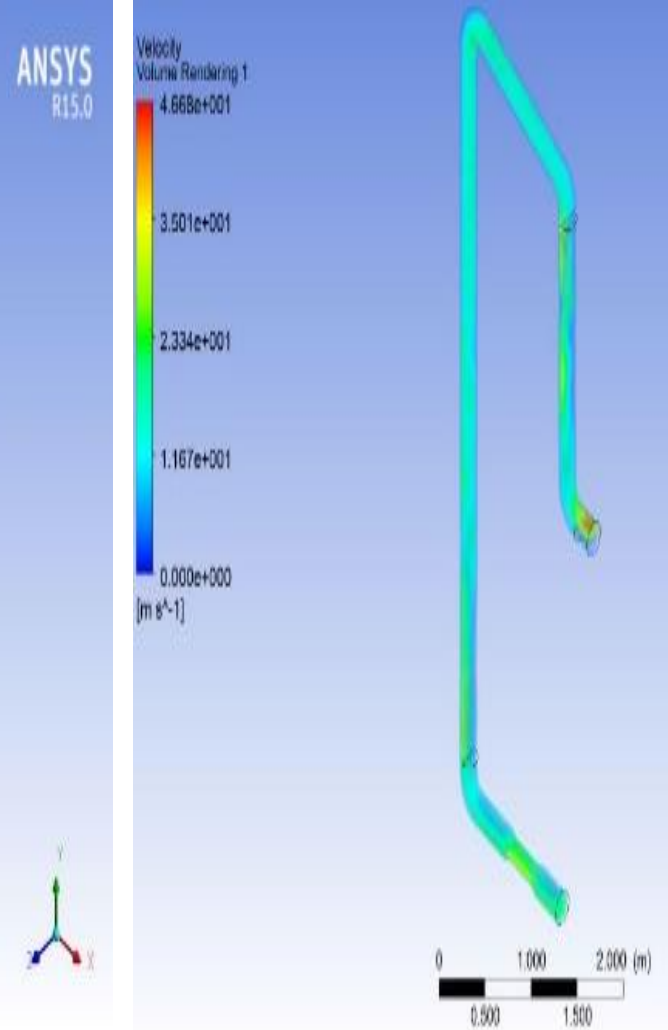

b)

Figure 7. Drying air temperature and speed distribution with $v_{u}$ variation of $15 \mathrm{~m} / \mathrm{s}: \mathrm{a}$ ) temperature contour, and b) speed contour

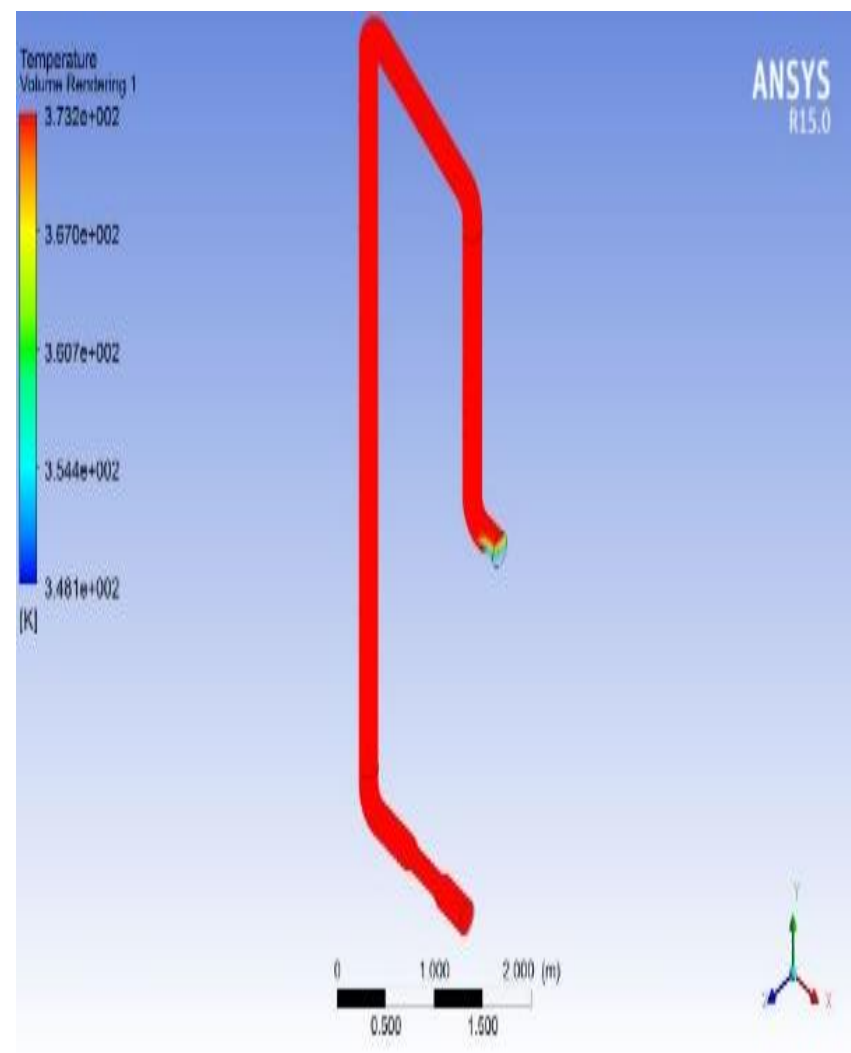

a)

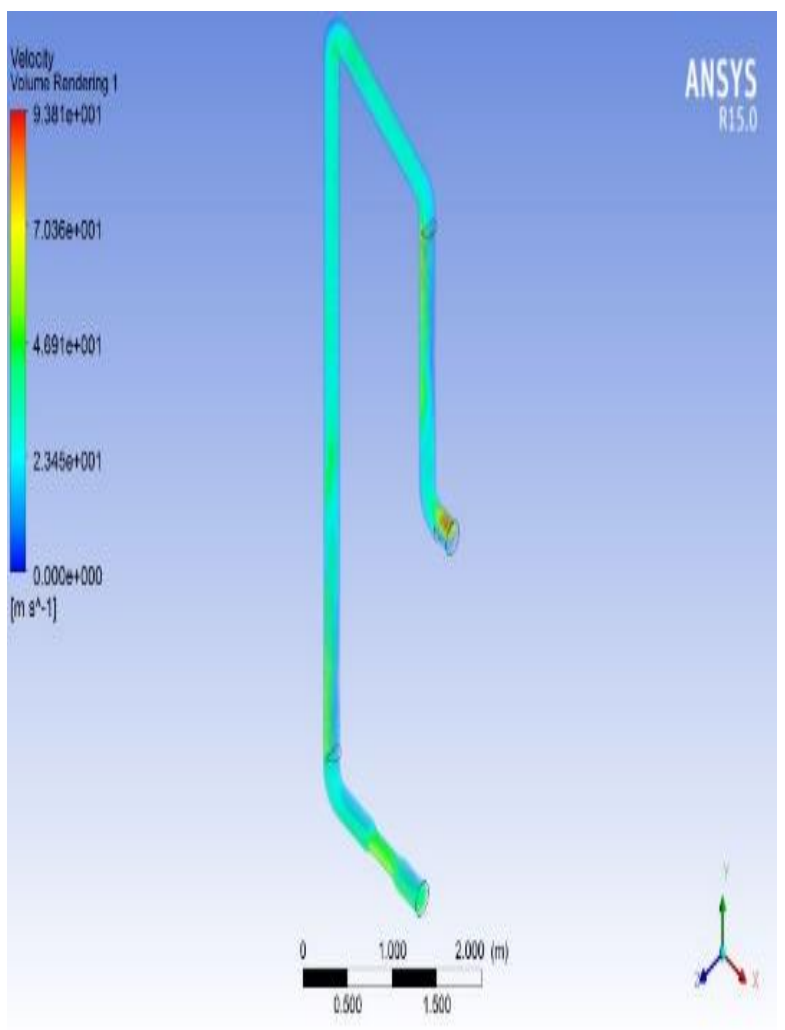

b)

Figure 8. Drying air temperature and speed distribution with $v_{u}$ variation of $31 \mathrm{~m} / \mathrm{s}: \mathrm{a}$ ) temperature contour, and b) speed contour 


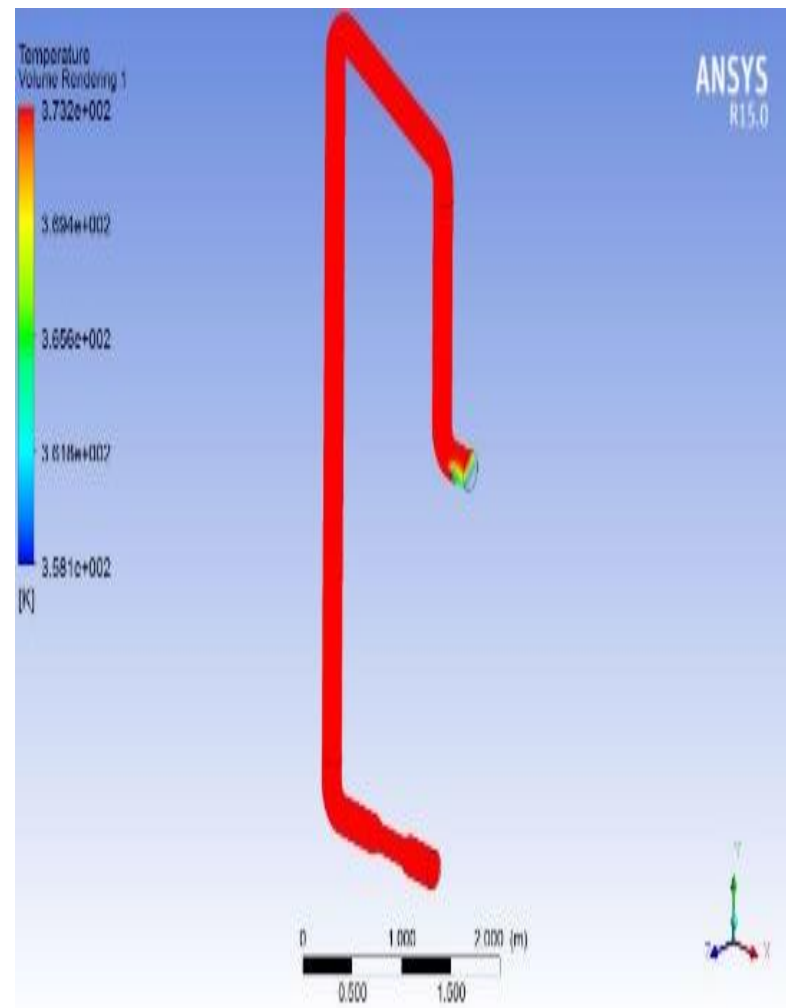

a)

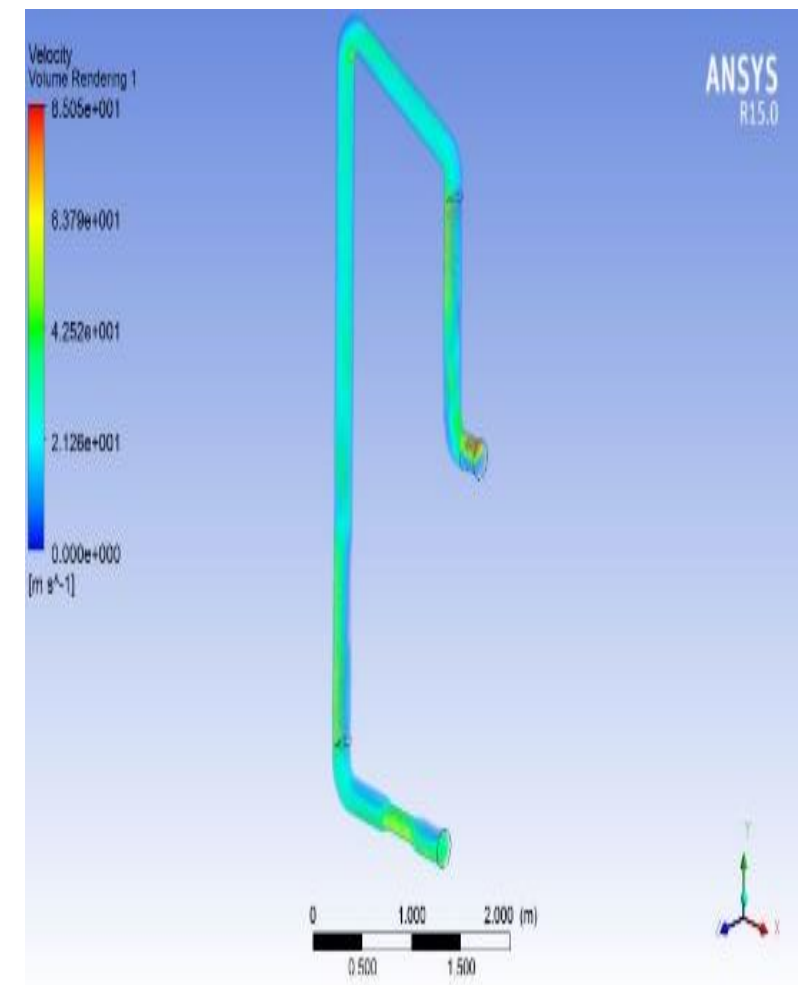

b)

Figure 9. Drying air temperature and speed distribution with $L_{p v}$ variation of $\left.5.8 \mathrm{~m}: a\right)$ temperature contour, and $b$ ) speed contour

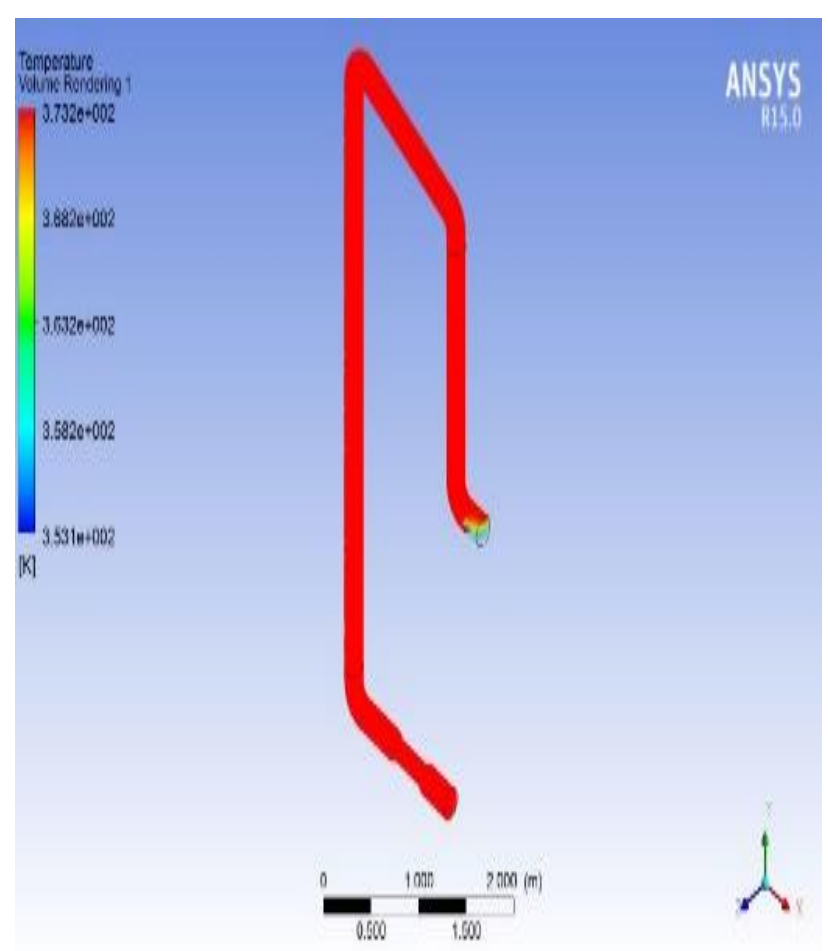

a)

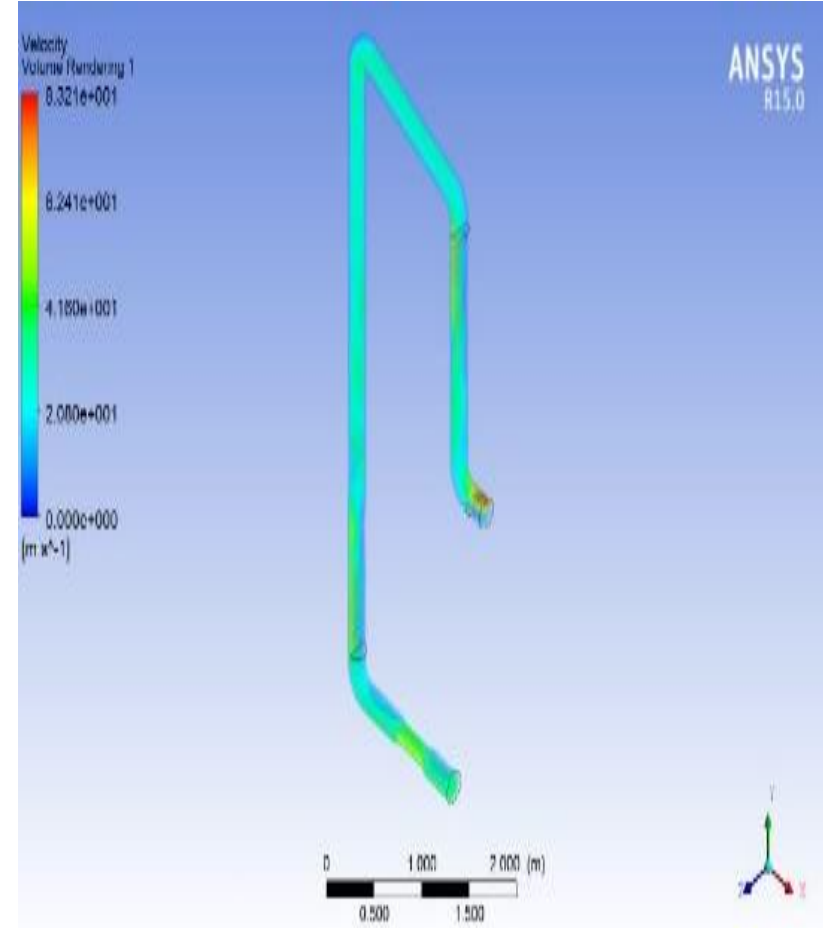

b)

Figure 10. Drying air temperature and speed distribution with $L_{p v}$ variation of $6.8 \mathrm{~m}: \mathrm{a}$ ) temperature contour, and $b$ ) speed contour 
The reduction of drying air temperature value did not influence the temperature value needed to reduce the water content of wet sago starch from $31 \%(\mathrm{wb})$ to $9 \%$ (wb) (Jading et al., 2018). This showed that the final water content of sago starch produced from the vertical and u-bend pipes design has fulfilled the required final water content set by Indonesia National Standard (SNI) for dry sago starch, that is, $13 \%$ (wb) (Badan Standar Nasional (BSN), 2008).

\section{Validation}

Figure 11 described validation. The error value produced was as follows: for $\mathrm{T}_{\mathrm{u} 1} 75^{\circ} \mathrm{C}$ was $1.21-2.88 \%$; Tu1 $100{ }^{\circ} \mathrm{C}$ was $0.20-2.04 \%$; and Tu1 $125^{\circ} \mathrm{C}$ was $0,81-$ $2,04 \%$. It was quite small, that is, less than $5 \%$. Statistics analysis using paired samples t-test with $T_{u 1} 75,100$, and $125^{\circ} \mathrm{C}$ showed that there was no significant difference between the results of simulation and observation along the vertical and u-bend pipes. Because the probability value obtained was greater than $\alpha 0.05$. The probability value obtained by $T_{u} 175,100$, and $125^{\circ} \mathrm{C}$ variations are, consecutively, 0.09; 0.064; and 0.09.
The comparison between simulation output and observation measurement (error) for drying air speeds of $15 \mathrm{~m} / \mathrm{s}$ and $31 \mathrm{~m} / \mathrm{s}$, with a constant drying air temperature of $100{ }^{\circ} \mathrm{C}$, can be seen in Figure 12 . The temperature error value of each drying air speed of $v_{u}$ $15 \mathrm{~m} / \mathrm{s}$ and $v_{u} 31 \mathrm{~m} / \mathrm{s}$ was similar, that is, 1.01-2.04\%. Just like in the temperature variations, the drying air speed variation error was also quite small, that is, less than $5 \%$. The probability value or sig (2-tailed) for $v_{u} 15$ $\mathrm{m} / \mathrm{s}$ and $31 \mathrm{~m} / \mathrm{s}$ is 0.08 . T-test showed that there was no significant difference between the result of simulation and observation.

The error value between the result of simulation and observation, based on the variation of vertical pipe lengths $\left(L_{p v}\right)$ of $5.8 \mathrm{~m}$ and $6.8 \mathrm{~m}$ can be seen in Figure 13. The error value of each of vertical pipe length variation was also quite small, that is, less than $5 \%$. The error value of temperature for $L_{p v} 5.8 \mathrm{~m}$ variation is $0.1-$ $1.7 \%$, and $L_{p v} 6.8 \mathrm{~m}$ variation is $0.15-1.8 \%$. The probability value or sig (2-tailed) of the pipe's length was 0.064 . This showed that there was no significant difference between the results of simulation and observation.

a)
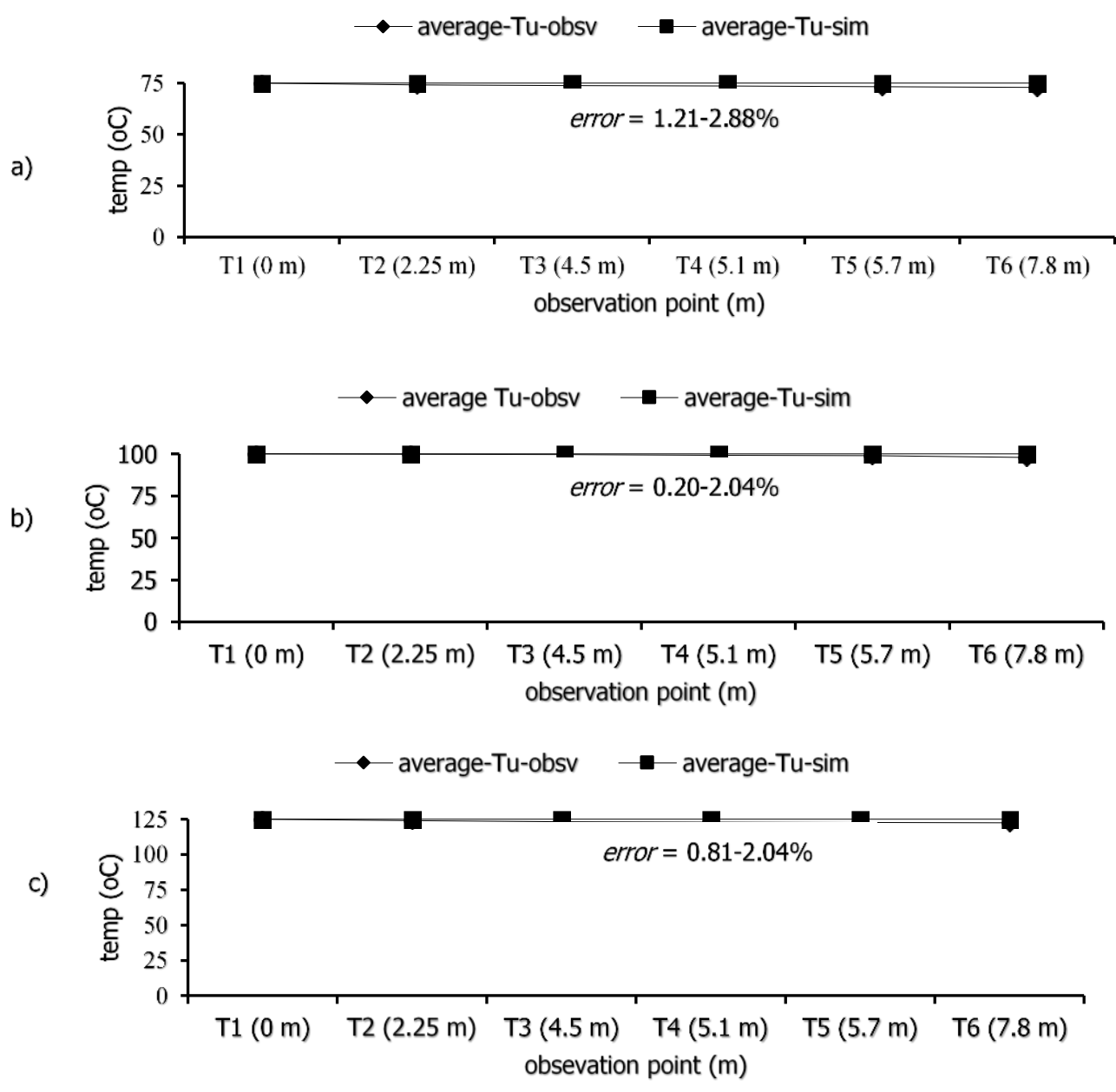

Figure 11. Comparison between drying air temperature as the result of simulation and observation: a) $\left.\mathrm{T}_{\mathrm{u} 1} 75^{\circ} \mathrm{C}, \mathrm{b}\right) \mathrm{T}_{\mathrm{u} 1}$ $100{ }^{\circ} \mathrm{C}$, and c) $\mathrm{T}_{\mathrm{u} 1} 125^{\circ} \mathrm{C}$ 
a)

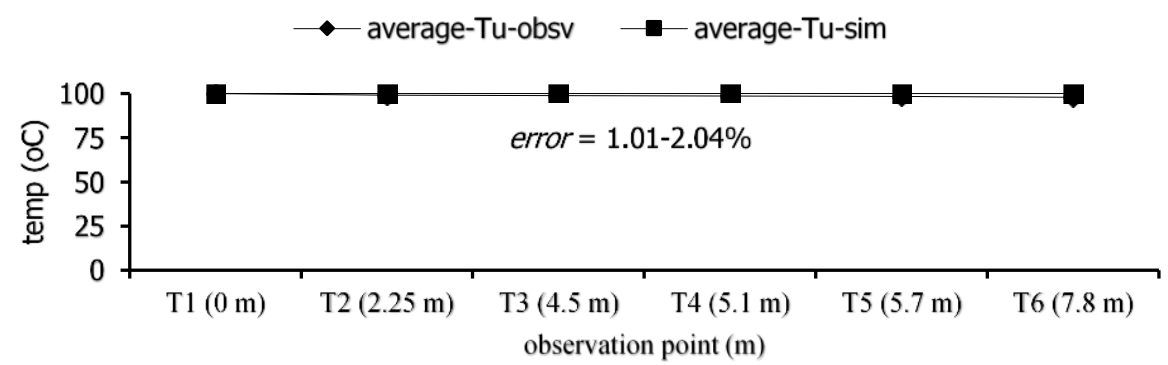

b)

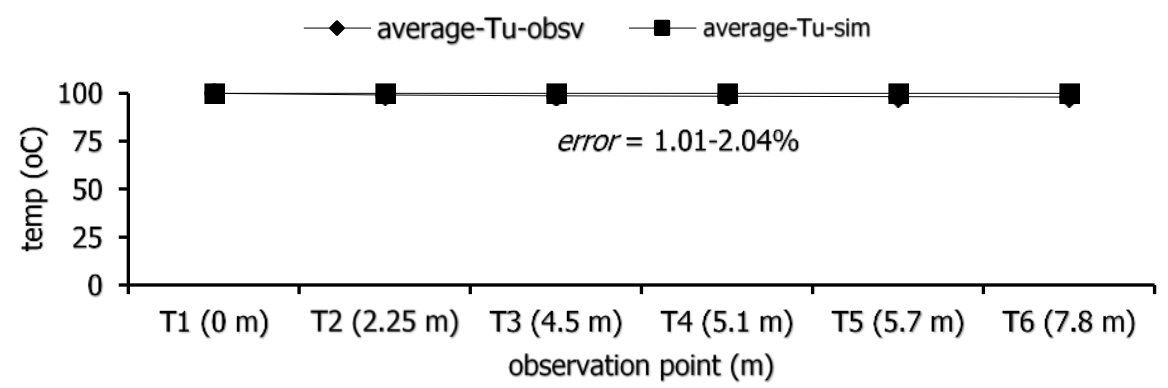

Figure 12. Comparison between drying air speed as the result of simulation and observation: a) $v_{u} 15 \mathrm{~m} / \mathrm{s}$, and b) $v_{u} 31 \mathrm{~m} / \mathrm{s}$

a)
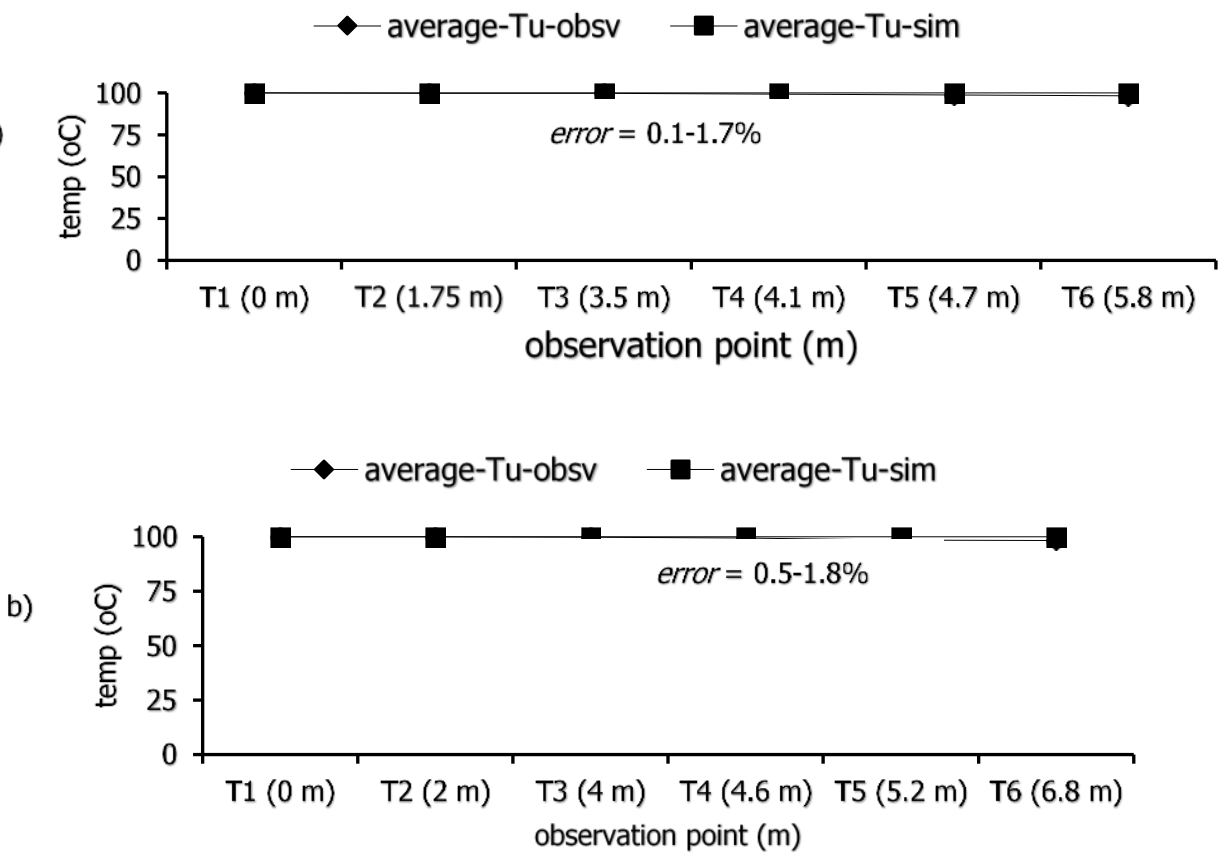

Figure 13. Comparison between drying air temperature as the result of simulation and observation: a) $L_{p v} 5.8 \mathrm{~m}$, and b) $L_{p v} 6.8 \mathrm{~m}$

The validation results showed the error value of temperature produced by each variation of $\mathrm{T}_{\mathrm{u} 1}, \mathrm{vu}$ and $\mathrm{L}_{\mathrm{pv}}$ treatments was quite small, that is, less than $5 \%$. Similarly, statistics analysis indicated that the probability value was greater than $\alpha 0.05$ value. So, there was no significant difference between the ansys fluent simulation output and the observation results, although the results of observation temperature measurement along the measurement points in the vertical and u-bend pipes of the PCRD machine experiences reduction. This was caused by a diabatic process along the vertical and $\mathrm{u}$ bend pipes by the outer surface of the pipes is not equipped with isolator. Moreover, the temperature reduction inside the pipes was also caused by the wet sago starch used throughout the testing process. This phenomenon in consistent with the results of a research by (Jading et al., 2018; Skuratovsky et al., 2005). 


\section{CONCLUSION}

Simulation showed that the heat along the vertical and u-bend pipes was well distributed, in which the error value between simulation and observation temperatures was quite small (0.1-2.04\%). Average paired t-test sample test showed that the ansys fluent simulation and observation were not significantly different. It indicated that the simulation results were close with the observation values or the real condition at the PCRD machine. The drying air temperature and speed distribution along the vertical and u-bend pipes coulb reduce water content of wet sago starch from $31 \%(w b)$ to $9 \%(w b)$. Therefore, the vertical and u-bend pipes design on the PCRD machine was feasible to be used in the drying process of wet sago starch.

\section{ACKNOWLEDGEMENT}

The author wishes to thank all persons who have helped the completion of this research, particularly the Directorate of Research and Community Service (DRPM), Ministry of Research and Technology and Higher Education, that has provided funding assistance through Doctoral Dissertation Research 2017. Also thanks to EMP and TPP laboratory technician staff of the Department of Agricultural Technology and Biosystem Engineering Faculty of Agricultural Technology UGM, and field assistants who have offered support in the making and testing of PCRD machine.

\section{REFERENCES}

Anisum, Bintoro, N., \& Goenadi, S. (2016). Analisis distribusi suhu dan kelembaban udara dalam rumah jamur (kumbung) menggunakan Computational Fluid Dynamics (CFD). Agritech, 36(1), 64-70.

Badan Standar Nasional (BSN). (2008). Tepung Sagu Kering. Jakarta, Indonesia.

Bhattarai, S., Oh, J. H., Euh, S. H., Kim, D. H., \& Yu, L. (2014). Simulation study for pneumatic conveying drying of sawdust for pellet production. Drying Technology, 32, 1142-1156. https://doi.org/10.1080/07373937.2014.884575.

Caroko, N., \& Suyitno. (2008). Perbandingan model turbulen spalart-Allmaras dan Reynolds stress model pada analisis efisiensi dan rugi tekanan siklon. Jurnal Semestas Teknika, 11(2), 199-206.

Dyah, W., Nelwan, L. O., Kamaruddin, A., \& Indra, A. S. (2003). Analisis distribusi suhu dan kecepatan aliran udara dalam ruang pengering berenergi surya menggunakan CFD. Buletin Keteknikan Pertanian, 171), 68-76.

El-Behery, S. M., El-Askary, W. A., Hamed, M. H., \& Ibrahim, K. A. (2013). Eulerian-Lagrangian simulation and experimental validation of pneumatic conveying dryer. Drying Technology, 31(12), 1374-1387. https://doi.org/10.1080/07373937.2013.796483.

Fluent, A. (2013a). Ansys Fluent 15.0 Tutorial Guide. Ansys INC (Vol. 15317). https://doi.org/10.1016/0140-3664(87)903112.

Fluent, A. (2013b). Ansys Fluent R15 Users Guide. USA: Ansys Inc. Retrieved from www.ansys.com.
Hidayat, M., \& Rasmuson, A. (2007). A computational investigation of non-isothermal gas-solid flow in a U-bend. Powder Technology, 175(2), 104-114. https://doi.org/10.1016/j.powtec.2007.01.024.

Jading, A., Bintoro, N., Sutiarso, L., \& Karyadi, J. N. (2016). Analisis efisiensi pneumatic conveying recirculated dryer untuk pengeringan bahan-bahan tepung. In Partoyo, Y. . Ratih, D. Mulyanto, \& S. Wuryani (Eds.), Seminar Nasional Fakultas Pertanian UPN Veteran Yogyakarta (pp. 370-378). Yogyakarta: Fakultas Pertanian UPN Veteran Yogyakarta.

Jamaleddine, T. J., \& Ray, M. B. (2011). Drying of sludge in a pneumatic dryer using computational fluid dynamics. Drying Technology, 29(3), 308-322. https://doi.org/10.1080/07373937.2010.496095.

Kornev, N. (2013). Mathematical Modeling of Turbulent Flows. Rostock Germany. Retrieved from www.lemos.unirostock.de/fileadmin/MSE_lemos/Lehre/Turbulence/Turbul enceDraft_of_future-manuscrift.pdf.

Norton, T., \& Sun, D. (2006). Computational fluid dynamics (CFD) - an effective design and analysis tool for the Food industry: Review. Trends in Food Science \& Technology, $17,600-620$.

Singh, R. P., \& Heldman, D. R. (2009). Introduction to Food Engineering (Fourth). Amsterdam: Elsevier.

Skuratovsky, I., Levy, A., \& Borde, I. (2005). Two-dimensional numerical simulations of the pneumatic drying in vertical pipes. Chemical Engineering and Processing: Process Intensification, 44(2), 187-192. https://doi.org/10.1016/j.cep.2004.02.012.

Tuakia, F. (2008). Dasar-dasar CFD Menggunakan Fluent (Pertama). Bandung: Informatika.

Yani, A., Suhardiyanto, H., Hasbullah, R., \& Purwanto, B. P. (2007). Analisis dan simulasi distribusi suhu udara pada kandang sapi perah menggunakan Computational Fluid Dynamics (CFD). Media Peternakan, 30(3), 218-228. 